Implementasi Mastery Learning Untuk Pencapaian Standar.

\title{
IMPLEMENTASI MASTERY LEARNING UNTUK PENCAPAIAN STANDAR KOMPETENSI SISWA \\ DALAM PEMBELAJARAN PENDIDIKAN AGAMA ISLAM DI SMA NEGERI 2 BOGOR
}

\author{
Mukhtar \\ SMA Negeri 2 Bogor \\ mukhtar02pai@gmail.com
}

\begin{abstract}
This study aims to describe the implementation of mastery learning (complete learning) in Islamic Religious Education learning (both planning, implementation, evaluation, learning outcomes and follow-up) in SMA Negeri 2 Bogor; also to provide a clear explanation of the implications of mastery learning on students' achievement of Competency Standards (SK) in Islamic Education learning. This research is a qualitative field research. The approach used is descriptive qualitative and data collection uses the method of observation, interviews, documentation and triangulation. The data analysis used was descriptive analytical and interpretive. The results show that SMA Negeri 2 Bogor has implemented the mastery learning strategy as an effort to achieve SK in learning (PAI), especially - more intensively - since the implementation of the CBC in 2004 and KTSP in 2006, but the implementation has not been maximal. and needs further improvement. Implementatively, the mastery learning strategy pays close attention to individual differences, marked by the existence of follow-up programs in the form of remedial, enrichment and acceleration programs, which of course become necessary being. so that students achieve competency completely. The implication is that the achievement of $S K$ depends on the achievement of Basic Competence (KD), and the achievement of KD is very dependent on the achievement of indicators, and vice versa. The completeness is based on the Minimum Completeness Criteria (KKM) that have been determined in Islamic Education learning, so that students have competence and performance that can be measured (measurable) and can be observed (observable) as an indicator of successful learning completely.
\end{abstract}

Keywords: Mastery Learning, Competency Standards, Islamic Religious Education

\section{PENDAHULUAN}

Pendidikan merupakan pekerjaan besar dan bentuk investasi jangka panjang, sedangkan hasilnya baru dapat dirasakan beberapa puluh tahun

214 | FENOMENA, Vol.19 No. 2 Oktober 2020 
kemudian. Pendidikan bukan sekedar proses alih budaya (transfer of culture) dan alih pengetahuan (transfer of knowledge), tetapi sekaligus sebagai proses alih keterampilan hidup (transfer of life skills) dan alih nilai (transfer of values). ${ }^{1}$ Tentunya hal ini memerlukan proses yang panjang diantaranya melalui pengembangan dan penyesuaian kurikulum yang ada.

Kurikulum pendidikan di Indonesia selalu mengalami penyempurnaan dan penyesuaian. Penyempurnaan kurikulum tersebut merupakan upaya peningkatan mutu pendidikan. Indikator keberhasilan pembaharuan kurikulum ditunjukkan dengan adanya perubahan pola kegiatan pembelajaran. Seperti halnya, perubahan dari kurikulum berbasis isi (contentbased curriculum) menjadi kurikulum berbasis kompetensi (competency-based curriculum) mengakibatkan perubahan paradigma dalam proses pembelajaran yaitu apa yang harus diajarkan (isi) menjadi apa yang harus dikuasai siswa (kompetensi). Perubahan kurikulum tersebut menurut Mulyasa mengakibatkan pergeseran paradigma dari pendekatan pendidikan yang berorientasi masukan (input-oriented education) ke pendekatan yang berorientasi hasil atau standar (outcomes-based education), tentunya berimplikasi pada cara guru mendesain proses pembelajaran. ${ }^{2}$ Hasil dari penyempurnaan dan penyesuaian kurikulum itu, sekarang diberlakukan Kurikulum Tingkat Satuan Pendidikan (KTSP) tahun 2006. Peran dan kepekaan guru terhadap perkembangan dan perubahan kurikulum dimaksud, mendorongnya untuk selalu mengadakan inovasi dan kreatifitas dalam menyusun strategi pembelajaran yang kreatif dan menyenangkan (joyful learning) serta penuh makna (meaningful learning). Karena bagaimanapun bagus dan idealnya kurikulum yang disusun, sangat bergantung pada bagaimana kemampuan pendidik (guru) untuk mengimplementasikan dan mengembangkannya secara aplikabel dalam pembelajaran, apapun nama dan jenis kurikulum yang digunakan.

${ }^{1}$ Tim Peneliti Depag RI, Pedoman Penilaian Pendidikan Agama Islam Berbasis Kompetensi di Sekolah Menengah Atas, Jakarta: Departemen Agama Rl, Balitbang Agama dan Diklat Keagamaan Puslitbang Pendidikan Agama dan Keagamaan, 2004, h. 10; Azizy, A. Qodry, Pendidikan [Agama] Untuk Membangun Etika Sosial, Semarang: Aneka IImu, 2002, h. 19; Karim, M. Rusli, "Pendidikan Islam Sebagai Upaya Pembebasan Manusia", dalam Muslih Usa (Editor), Pendidikan Islam di Indonesia Antara Cita dan Fakta, Yogyakarta: Tiara Wacana, 1991, h. 27.

2 Mulyasa, Kurikulum Berbasis Kompetensi: Konsep, Karakter, dan Implementasi, (Bandung: PT. Remamaja Rosdakarya, 2006), 11

FENOMENA, Vol.19 No. 2Oktober 2020 | 215 
Secara lebih khusus, diberlakukannya KTSP sebagai kurikulum berbasis kompetensi dalam pembelajaran Pendidikan Agama Islam (PAI) dilatarbelakangi oleh beberapa faktor, yaitu: (1) pendidikan agama dianggap masih kurang memberikan kontribusi terhadap pembentukan watak dan kepribadian siswa, serta belum sepenuhnya menjadi etika dan moral dalam bertingkah laku sesuai ajaran agama, (2) pelaksanaan pendidikan agama lebih terfokus pada pengayaan pengetahuan (kognitif), mengabaikan pembentukan sikap (afektif) dan pembiasaan (psikomotorik), (3) lemahnya sumber daya guru dalam mengembangkan pendekatan, strategi, model, atau metode yang sesuai dengan kebutuhan siswa, (4) implikasi dari ketiga hal di atas, penilaian pun lebih difokuskan pada penguasaan materi (aspek kognitif), mengabaikan aspek afektif dan psikomotorik. ${ }^{3}$ Untuk menghindari kondisi semacam ini, tentunya diperlukan visi pendidikan Indonesia ke depan agar memiliki generasi bangsa yang dapat merealisasikan fungsi dan tujuan pendidikan nasional.

Pendekatan dalam pembelajaran PAI memiliki karakteristik tertentu agar lebih bermutu sebagai berikut: ${ }^{4}$ (1) berorientasi pada pencapaian hasil dan dampaknya (outcome oriented), (2) bertolak dari kompetensi tamatan/lulusan, (3) berbasis pada Standar Kompetensi (SK) dan Kompetensi Dasar (KD), (4) pengembangan kurikulum yang menghargai perbedaan-perbedaan (berdiferensiasi), (5) utuh dan menyeluruh (bolistik), dan (6) menerapkan prinsip ketuntasan belajar (mastery learning).

Mutu pembelajaran tergantung pada pemilihan strategi yang tepat dalam upaya mengembangkan kreatifitas dan sikap inovatif subjek didik. Untuk itu diperlukan dan dikembangkan kemampuan (kompetensi) guru secara profesional untuk mengelola program pembelajaran dengan strategi belajar yang kaya dengan variasi. Strategi pembelajaran didesain oleh guru

\footnotetext{
${ }^{3}$ Depdiknas, Pedoman Khusus Pengembangan Silabus dan Penilaian, Jakarta: Dirjen Dikdasmen: Direktorat Dikmenum.2003, h. 3; Depdiknas, Model Penilaian Kelas Kurikulum Berbasis Kompetensi, Dirjen Dikdasmen: Direktorat Dikmenum, 2007, h. 3-4.

4 Tim Peneliti Depag RI, Pedoman Penilaian Pendidikan Agama Islam Berbasis Kompetensi di Sekolah Menengah Atas, Jakarta: Departemen Agama RI, Balitbang Agama dan Diklat Keagamaan Puslitbang Pendidikan Agama dan Keagamaan, 2004, h. 10; Azizy, A. Qodry, Pendidikan [Agama] Untuk Membangun Etika Sosial, Semarang: Aneka IImu, 2002, h. 19; Karim, M. Rusli, "Pendidikan Islam Sebagai Upaya Pembebasan Manusia", dalam Muslih Usa (Editor), Pendidikan Islam di Indonesia Antara Cita dan Fakta, Yogyakarta: Tiara Wacana, 1991, h. 27.
}

216 | FENOMENA, Vol.19 No.2Oktober 2020 
dengan segala karakteristiknya, didasari oleh adanya perbedaan individu (individual difference) sebagai pembelajar. Pemahaman akan adanya perbedaan individu merupakan suatu hal yang niscaya (necessary being). Argumentasi ini dibangun karena siswa menurut Sutrisno. ${ }^{5}$ memiliki perbedaan minat (interest), kemampuan (ability), kesenangan (preference), pengalaman (experience), dan cara belajar (learning style).

Sebagai konsekuensi logis dari KTSP berbasis kompetensi, dalam pelaksanaan pembelajaran PAI, diperlukan adanya perubahan pengorganisasian materi, pendekatan dan metode pembelajaran, kelengkapan sarana dukung pembelajaran, serta sistem penilaian yang sesuai dengan tuntutan kompetensi dasar yang ditetapkan. ${ }^{6}$ Guru yang kreatif, profesional, dan menyenangkan dalam mengembangkan strategi pembelajaran, tentunya akan mendorong siswa mencapai kompetensi belajarnya sesuai dengan karakteristik individual masing-masing secara tuntas (mastery learning) menurut kriteria yang telah ditentukan.

\section{Tinjauan Pustaka}

\section{a. Paradigma Mastery Learning (Belajar Tuntas) Dalam Pembelajaran PAI}

1. Hakikat Pembelajaran

Penggunaan istilah "pembelajaran" ini menurut Sanjaya mengisyaratkan bahwa dalam proses belajar mengajar siswa harus dijadikan sebagai pusat (student centered) dari kegiatan pembelajaran. ${ }^{7}$ Pembelajaran itulanjut Sanjaya, perlu memberdayakan semua potensi siswa untuk menguasai kompetensi yang diharapkan. Pemberdayaan diarahkan untuk mendorong pencapaian kompetensi supaya setiap individu mampu menjadi pembelajar

\footnotetext{
${ }^{5}$ Sutrisno, Revolusi Pendidikan di Indonesia, Membahas tentang Metode dan Teknik Berbasis Kompetensi, (Yogyakarta: Ar-ruz, 2005), 63.

${ }^{6}$ Ada tiga faktor penting menurut Supriyoko (Kompas, 9 Juli 2002), yang berpengaruh terhadap keberhasilan pendidikan, yaitu: (1) hardware, (2) software, dan (3) brainware. Hardware meliputi ruang belajar, peralatan praktek, laboratorium, perpustakaan. Software, misalnya kurikulum, program pembelajaran, manajemen sekolah, sistem pembelajaran. Brainware antara lain guru, kepala sekolah, siswa, dan orang-orang yang terkait dalam pembelajaran. Dari sekian faktor tersebut, yang paling penting dan menentukan adalah faktor guru.

${ }^{7}$ Sanjaya, Wina, Strategi Pembelajaran: Berorientasi Standar Proses Pendidikan,( Jakarta: Kencana Prenada Media Group, 2008),103.
}

FENOMENA, Vol.19 No.2Oktober 2020 | 217 
sepanjang hayat (life long education) dan mewujudkan masyarakat belajar (learning community). Secara konsepsional penggunaan istilah pembelajaran terkait erat dengan desain pembelajaran-terutama dalam rangka membelajarkan siswa. Untuk itu, menurut Muhaimin, $\mathrm{dkk}^{8}$ penggunaan istilah pembelajaran secara konsepsional memiliki implikasi pedagogis, yaitu: Pertama, perlu diusahakan agar proses pembelajaran yang dilakukan berlangsung secara interaktif antara siswa dengan sumber belajar. Kedua, bagi siswa, dalam pembelajaran dapat berlangsung interaksi internal yang melibatkan seluruh potensi yang dimilikinya dengan sumber belajar.

Darsono $^{9}$ dan Kunandar ${ }^{1}$ sependapat bahwa pembelajaran adalah suatu kegiatan yang dilakukan oleh guru dengan sedemikian rupa sehingga tingkah laku siswa berubah ke arah yang lebih baik. Konsep pembelajaran tersebut jika dikaitkan dengan Kurikulum Tingkat Satuan Pendidikan (KTSP) berbasis kompetensi, menjadi lebih terlihat interaksi siswa dengan lingkungan secara edukatif-operasional. Lebih lanjut Kunandar menjelaskan bahwa pembelajaran dalam KTSP adalah pembelajaran di mana hasil belajar atau kompetensi yang diharapkan oleh siswa, sistem penyampaian, dan indikator pencapaian hasil belajar dirumuskan secara tertulis sejak perencanaan dimulai.

Berdasarkan dari beberapa pengertian pembelajaran tersebut, dapat dipahami bahwa pembelajaran secara konsepsional mengandung pengertian yang konstruktif, yakni titik tekannya adalah membangun dan mengupayakan keaktifan siswa untuk mencapai kompetensi yang diinginkan. Argumen ini dibangun berdasarkan karakteristik pembelajaran itu sendiri sebagai suatu paradigma baru untuk membelajarkan siswa. Hal ini seperti dikemukakan oleh Naim dan Patoni bahwa karakteristik pembelajaran adalah: (1) pembelajaran berarti membelajarkan siswa, (2) proses pembelajaran berlangsung di mana saja, dan (3) pembelajaran berorientasi pada pencapaian tujuan. ${ }^{1}$ Karakteristik ini membêrikan legitimasi pembelajaran secara

\footnotetext{
${ }^{8}$ Muhaimin, et.al., Paradigma Pendidikan Islam: Upaya Mengefektifkan Pendidikan Agama Islam di Sekolah, (Bandung: Remaja Rosdakarya, 2002), 183

${ }^{9}$ Darsono, Max, dkk., Belajar dan Pembelajaran, (Semarang: IKIP Press, 2001), 24

1 Kunandar, Guru Profesional. Implementasi Kurikulum Tingkat Satuan Pendidikan (KTSP) dan Sukses dalam Sertifikasi Guru, (Jakarta: PT. RajaGrafindo Persada, 2007), 287.

1 Naim, Naginun dan Achmad Patoni, , Materi Penyusunan Desain Pembelajaran Pendidikan Agama Islam, (Yogyakarta, Pustaka Pelajar, 2007), 66.
}

218 | FENOMENA, Vol.19No.2Oktober 2020 
fungsional, yakni seperti yang dikemukan Ghofar dan Jamil bahwa pembelajaran bukan menaruh perhatian pada "apa yang dipelajari", tetapi lebih pada "bagaimana membelajarkan pembelajaran". ${ }^{1}$ Hal ini juga mengimplikasikan bahwa tujuan pembelajaran adalah membantu orang (siswa) untuk belajar, dan merekayasa lingkungan sehingga memberi kemudahan bagi orang yang belajar mencapai tujuannya (kompetensi). ${ }^{1}$

2. Kurikulum Berbasis Kompetensi dalam PAI di SMA

Sebagai sebuah konsep, sekaligus sebagai sebuah program, Kurikulum Berbasis Kompetensi (KBK) secara operasional memiliki karakteristik sebagai berikut: (1) menekankan pada ketercapaian kompetensi siswa baik secara individual maupun klasikal; (2) berorientasi pada hasil (learning outcomes) dan keberagaman (difrensiasi); (3) penyampaian dalam pembelajaran menggunakan pendekatan dan metode belajar yang bervariasi; (4) sumber belajar bukan hanya guru tetapi sumber lainnya yang memenuhi unsur edukatif; (5) penilaian menekankan pada proses dan hasil belajar dalam upaya penguasan suatu kompetensi. ${ }^{1}$ Berdasarkan hal ini, secara ${ }^{4}$ perasional kurikulum berbasis kompetensi (KBK) dalam PAI merupakan bagian KTSP, yakni merupakan suatu konsep pembelajaran yang lebih menekankan pada pengembangan kemampuan melakukan (kompetensi) tugas-tugas dengan standar performansi tertentu, sehingga hasilnya dapat dirasakan siswa berupa penguasaan terhadap seperangkat kompetensi tertentu.

a) Kompetensi dalam Pembelajaran PAI di SMA

Istilah competency berasal dari kata competen, menurut Echols dan Shadily berarti kecakapan, kemampuan, dan kewenangan. ${ }^{1}$ Sementara menurut

1 Ghofar, Irfan Abdul dan MuRammad Jamil, Reformulasi Rancangan Pembelajaran Agama Islam: Pedoman Dosen dan Mahasiswa, (Jakarta: Nur Insani, 2003), 22.

1 Sanjaya, Wina, Strategi Pembelajaran: Berorientasi Standar Proses Pendidikan,( Jakarta: Kencana Prenada Media Group, 2008), 58

1 Nurhadi dan Agus Gerrad Senduk, 2001, Pembelajaran Contextual (Contextual Teaching and Learning) dan Penerapannya dalam KBK, Malang: Universitas Negeri Malang, 2003, h. 99; Mulyasa, Kurikulum Berbasis Kompetensi h. 42 ; Depdiknas, The Mastery Learning for the 2004 Curriculum, Jakarta: Dirjen Dikdasmen Direktorat Pendidikan Menengah Umum, 2003, h. 10; Tim Peneliti Depag, op.cit., h. 17.

1 John dan Hassan Shadily, Kamus Inggris Indonesia, (Jakarta: Gramedia, 1996), 132.

FENOMENA, Vol.19 No. 2Oktober 2020 | 219 
Poerwadarminta kompetensi diartikan dengan kewenangan atau kekuasaan untuk memutuskan atau menentukan suatu tindakan. ${ }^{1}$

McAhsan (1981) mendefinisikan kompetensi dengan "Competency is knowledge, skill, and abilities or capabilities that person achieves, which become part of his or her being to the exent he or she can satisfactorily perform particular cognitive, affective, and psychomotor behavior" (kompetensi adalah sebuah pengetahuan, keterampilan dan kemampuan yang dikuasai oleh seseorang dan telah menjadi bagian dari dirinya sehingga dapat melakukan perilaku-perilaku kognitif, afektif, dan psikomotor dengan sebaik-baiknya). ${ }^{1}$

Pengertian kompetensi dalam pembelajaran secara singkat dirumuskan oleh Mulyasa bahwa kompetensi dalam pembelajaran merupakan perpaduan pengetahuan, keterampilan, dan nilai-nilai dasar yang direfleksikan dalam kebiasaan berpikir dan bertindak sesuai dengan tujuan yang diharapkan. ${ }^{1}$ Beberapa aspek atau ranah yang terkandung dalam kompetensi, menurut Gordon (1988) adalah (a) pengetahuan (knowledge), (b) pemahaman (understanding), (c) kemampuan (skill), (d) nilai (value), (e) sikap (attitude), dan (f) minat (interest). ${ }^{1}$

Merujuk pada beberapa pengertian di atas, maka dapat ditarik kesamaan bahwa kompetensi menunjuk pada: (1) seperangkat kemampuan standar yang diperlukan untuk menjalankan tugas pokok dan fungsinya secara maksimal, (2) kemampuan yang dimiliki seseorang, baik kemampuan performance maupun kemampuan rasional, (3) mencakup pengetahuan, keterampilan, sikap dan nilai, (4) menekankan pada perilaku yang terukur sebagai aplikasi dari kompetensi yang dimiliki, (5) menekankan pada outcomes, (6) kompetensi digunakan untuk konteks tertentu yang mungkin berbeda dari tempat yang satu dan tempat yang lainnya, (7) kompetensi merupakan tujuan dalam kurikulum yang bersifat komplek dan menyeluruh, (8) tujuan yang ingin dicapai dalam kompetensi bukan sekedar pemahaman materi pelajaran, tetapi lebih pada bagaimana penguasaan itu berpengaruh pada cara bertindak dan berprilaku dalam kehidupan sehari-hari.

\footnotetext{
1 Poerwadarminta, W.J.S., Kaß́nus Umum Bahasa Indonesia, (Jakarta: Balai Pustaka, 1997), 518

1 Mulyasa, Kurikulum Berbasłs Kompetensi: Konsep, Karakter, dan Implementasi, (Bandung: PT. Remamaja Rosdakarya, 2006), 38.

1 Mulyasa, 37

1 Mulyasa, 38-39
}

220 | FENOMENA, Vol.19 No. 2 Oktober 2020 
Berdasarkan Permendiknas Nomor 24 tahun 2006 tentang pelaksanaan Permendiknas Nomor 22 dan 23 tahun 2006, kompetensi mata pelajaran (termasuk PAI) terbagi pada tiga klasifikasi,. yaitu:: 1) Standar Kompetensi Lulusan (SKL), yaitu batas kemampuan minimal yang harus dicapai oleh siswa setelah tamat mengikuti pendidikan pada jenjang atau satuan pendidikan tertentu. Misalnya kompetensi lulusan SMA. SKL ini kemudian dijabarkan menjadi standar kompetensi. Dilihat dari tujuan kurikulum, SKL termasuk tujuan institusional (lembaga). 2) Standar Kompetensi (SK), yaitu batas kemampuan minimal yang harus dicapai setelah siswa menyelesaikan proses pembelajaran suatu mata pelajaran tertentu pada setiap jenjang atau satuan pendidikan yang diikutinya. Misalnya, kompetensi yang harus dicapai oleh mata pelajaran PAI di SMA. SK ini kemudian dijabarkan lebih rinci lagi menjadi kompetensi dasar. Dilihat dari tujuan kurikulum, SK termasuk pada tujuan kurikuler (tujuan mata pelajaran). 3) Kompetensi Dasar (KD), yaitu batas kemampuan minimal yang harus dicapai siswa dalam penguasaan materi pelajaran yang diberikan dalam satuan (unit) pembelajaran pada jenjang pendidikan tertentu. KD ini kemudian dijabarkan lagi menjadi indikatorindikator keberhasilan belajar. KD ini sebelumnya disebut dengan tujuan pembelajaran umum (TPU).

b) Pembelajaran Berbasis Kompetensi dalam PAI di SMA

Pembelajaran berbasis kompetensi merupakan suatu proses pembelajaran yang perencanaan, pelaksanaan dan penilaiannya mengacu kepada penguasaan kompetensi. Pembelajaran berbasis kompetensi dimaksudkan agar segala upaya yang dilakukan dalam proses pembelajaran benar-benar mengacu dan mengarahkan siswa untuk mencapai penguasaan kompetensi yang telah diprogramkan dalam Rencana Pelaksanaan Pembelajaran (RPP).

Terdapat beberapa hal yang melandasi perlunya diterapkan kurikulum yang berorientasi pada kompetensi dalam pembelajaran (PAI), yaitu: Pertama, adanya pergeseran sistem pembelajaran dari pembelajaran klasikal ke pembelajaran individual. Kedua, adanya tuntutan pembelajaran tuntas (mastery learning)), yang mempersyaratkan siswa untuk menguasai seluruh kompetensi yang ditetapkan. Ketiga, adanya asumsi baru bahwa seluruh siswa mampu menguasai kompetensi yang ditetapkan, jika diberi waktu yang cukup dan 
perlakuan yang sesuai dengan potensi yang dimiliki masing-masing individu. $^{2}$

Berdasarkan hal tersebut, maka sistem pembelajaran dalam KTSP berbasis kompetensi, pelaksanaannya diorientasikan pada upaya membelajarkan siswa serta memfasilitasi dalam berinteraksi dengan lingkungannya. Maksud dan tujuannya adalah untuk mempermudah pencapaian kompetensi yang diharapkan dengan memaksimalkan berbagai potensi sumber belajar (learning resourcess) yang dimiliki sekolah, baik yang direncanakan untuk kepentingan belajar (learning resourcess by design) maupun yang dimanfaatkan (learning resourcess by utilization). Semua itu merupakan realisasi pendidikan berbasis luas (Broad Based Education).

3. Landasan Konseptual Mastery Learning (Belajar Tuntas)

a) Konsep Dasar Mastery Learning

Mastery learning dalam KTSP adalah pendekatan pembelajaran yang mensyaratkan siswa menguasai secara tuntas seluruh standar kompetensi maupun kompetensi dasar mata pelajaran tertentu. ${ }^{2}$ Pengertian ini menunjukkan bahwa mastery learning merupakan strategi pembelajaran yang dapat dilaksanakan di dalam kelas, dengan tujuan agar sebagian besar siswa dapat menguasai tujuan pembelajaran (kompetensi) secara tuntas ${ }^{2}$. Mastery learning merupakan proses pembelajaran yang dilakukan secara sistematis dan terstruktur, bertujuan untuk mengadaptasikan pembelajaran pada siswa kelompok besar (klasikal), membantu mengatasi perbedaan-perbedaan yang terdapat pada siswa dan berguna untuk menciptakan kecepatan belajar (rate of progress). ${ }^{2}$ Pendekatan ini bersifat ${ }^{3}$ individual dan diharapkan mampu

2 Tim Peneliti Depag RI, Pedoman Penilaian Pendidikan Agama Islam Berbasis Kompetensi di Sekolah Menengah Atas, (Jakarta: Departemen Agama RI, Balitbang Agama dan Diklat Keagamaan Puslitbang Pendidikan Agama dan Keagamaan, 2004), 17 dan Mulyasa, Kurikulum Berbasis Kompetensi: Konsep, Karakter, dan Implementasi, (Bandung: PT. Remamaja Rosdakarya, 2006), 40-41

2 Depdiknas, Pedoman Pembelajaran Tuntas (Mastery Learning), (Jakarta: Dirjen Dikdasmen: Direktorat Pendidikan Menengah Umum, 2004), 12.

2 Mulyasa, Kurikulum Berbasłs Kompetensi: Konsep, Karakter, dan Implementasi, (Bandung: PT. Remamaja Rosdakarya, 2006), 53 Kunandar, Guru Profesional: Implementasi Kurikulum Tingkat Satuan Pendidikan (KTSP) dan Sukses dalam Sertifikasi Guru, (Jakarta: PT. RajaGrafindo Persada, 2007), 237

2 Lihat lebih lanjut Depdiknas, ${ }^{3}$ The Mastery Learning for h. 1; Yamin, Martinis, 2006, Sertifikasi Profesi Keguruan di Indoenesia, Jakarta: Gaung Persada Press, 


\section{Mukhtar}

mengatasi kelemahan-kelemahan pembelajaran yang bersifat klasikal. Artinya, mastery learning merupakan suatu pendekatan pembelajaran yang menganut azas ketuntasan belajar, dengan tolok ukur yang digunakan pada pencapaian hasil belajar, yakni tingkat kemampuan siswa orang perorang, bukan perkelas dalam mencapai kompetensi yang telah ditetapkan. Pembelajaran individual (individualized instruction) merupakan ciri khas dari mastery learning ini. Pembelajaran PAI dalam KTSP sebagai kurikulum berbasis kompetensi, menjadikan mastery learning sebagai suatu keniscayaan (necessary being) dan bagian integral yang tak dapat dipisahkan.

b) Asumsi Dasar Mastery Learning

Mastery learning-dalam KTSP berbasis kompetensi-merupakan pendekatan dalam pembelajaran yang mempersyaratkan siswa menguasai secara tuntas seluruh standar kompetensi maupun kompetensi dasar mata pelajaran tertentu. Oleh karena itu, dalam model yang paling sederhana, $\mathrm{Carrol}^{2}$ mengemukakan bahwa jika setiap siswa diberikan waktu sesuai dengan yang diperlukan untuk mencapai suatu tingkat penguasaan, dan jika dia menghabiskan waktu yang diperlukan, maka besar kemungkinan siswa akan mencapai tingkat penguasaan kompetensi. Tetapi jika siswa tidak diberi cukup waktu atau dia tidak dapat menggunakan waktu yang diperlukan secara penuh, maka tingkat penguasaan kompetensi siswa tersebut belum optimal. Block (1971). ${ }^{2}$ dalam menyatakan tingkat ${ }^{5}$ penguasaan kompetensi siswa berikut:

$$
\text { Degree of learning } \quad=f\left(\frac{\text { Time actually spent }}{\text { Time needed }}\right)
$$

Model ini menggambarkan bahwa tingkat penguasaan kompetensi (degree of learning) ditentukan oleh seberapa banyak waktu yang benar-benar

2006, h. 136; juga Yamin, Martinis, Profesionalisasi Guru dan Implementasi KTSP, (Jakarta: Gaung Persada Press, 2007), 121

2 Depdiknas, Pedoman Pembelajaran Tuntas (Mastery Learning), (Jakarta: Dirjen Dikdasmen: Direktorat Pendidikan Menengah Umum, 2004), 12

2 Depdiknas, Pedoman Pembélajaran Tuntas (Mastery Learning), (Jakarta: Dirjen Dikdasmen: Direktorat Pendidikan Menengah Umum, 2004), 12.

FENOMENA, Vol.19 No. 2Oktober 2020 | 223 
digunakan (time actually spent) untuk belajar dibagi dengan waktu yang diperlukan (time needed) untuk menguasai kompetensi tertentu.

Mastery learning berasumsi bahwa di dalam kondisi yang tepat, semua siswa mampu belajar dengan baik dan memperoleh hasil yang maksimal terhadap seluruh materi yang dipelajari. Agar semua siswa memperoleh hasil yang maksimal, pembelajaran harus dilaksanakan dengan sistematis. ${ }^{2}$ Kesistematisan akan tercermin dari strategi pembelajaran yang dilaksanakan, terutama dalam mengorganisasi tujuan dan bahan belajar, melaksanakan evaluasi dan memberikan bimbingan terhadap siswa yang lambat mencapai tujuan (kompetensi) yang telah ditetapkan.

c) Prinsip-Prinsip Mastery Learning

Secara tegas dapat dikatakan bahwa sistem pembelajaran yang menggunakan prinsip mastery learning adalah tidak menerima perbedaan prestasi belajar siswa sebagai konsekuensi perbedaan bakat. ${ }^{2}$ Pada posisi ini, prinsip mastery learning adalah menciptakan dan membelajarkan siswa untuk belajar (learning how to learn) agar dapat mencapai tujuan pembelajaran (kompetensi). Melalui prinsip mastery learning semua siswa akan mencapai kompetensi, hanya saja waktu yang diperlukan berbeda.

Oleh karena itu, Gentile \& Lalley (2003) mengemukakan prinsipprinsip utama mastery learning yaitu: (1) Kompetensi yang harus dicapai siswa dirumuskan dengan urutan yang hirarkis, (2) Evaluasi yang digunakan adalah penilaian acuan patokan, dan setiap kompetensi harus diberikan feedback (umpan balik), (3) Pemberian pembelajaran remedial serta bimbingan yang diperlukan, dan (4) Pemberian program pengayaan bagi siswa yang mencapai ketuntasan belajar lebih awal. ${ }^{2}$ 8

Berdasarkan uraian tersebut dapatlah dipahami bahwa prinsip mastery learning adalah: Pertama, ditetapkan batas minimal tingkat kompetensi yang harus dikuasai oleh siswa. Kedua, menggunakan pendekatan Penilaian Acuan Patokan (PAP) untuk menilai keberhasilan belajar siswa mencapai Standar Ketuntasan Minimal (KKM). Ketiga, siswa tidak diperbolehkan pindah ke

2 Mulyasa, Kurikulum Berbasł́s Kompetensi: Konsep, Karakter, dan Implementasi, (Bandung: PT. Remamaja Rosdakarya, 2006), 53

2 Mulyasa, Standar Kompetensi dan Sertifikasi Guru, (Bandung: PT. Remaja Rosdakarya, 2008), 53; Hamalik, Oemar, Proses Belajar Mengajar, (Bandung : Bumi Akasara, 2003),84

2 Depdiknas, Pedoman Pembêlajaran Tuntas (Mastery Learning), (Jakarta: Dirjen Dikdasmen: Direktorat Pendidikan Menengah Umum, 2004), 14

224 | FENOMENA, Vol.19 No. 2 Oktober 2020 


\section{Mukhtar}

topik atau tugas berikutnya, jika topik atau tugas yang sedang dipelajarinya belum dikuasai sampai standar minimal. Keempat, memberikan kemampuan yang utuh, mencakup aspek pengetahuan, keterampilan, dan sikap. Kelima, setiap peserta diberi kesempatan untuk mencapai standar minimal, sesuai dengan irama dan kemampuan belajarnya masing-masing (individualized learning). Keenam, disediakan program bimbingan remedial bagi peserta yang lambat (slow learner), dan program pengayaan bagi peserta yang lebih cepat (fast learner) menguasai kompetensi serta percepatan (acceleration) bagi anak yang superior dan istimewa.

d) Strategi Pelaksanaan Mastery Learning

Strategi mastery learning apabila dilakukan pada kondisi yang tepat, maka semua siswa akan mampu belajar dengan baik dan dapat mencapai hasil yang maksimal. Agar semua siswa memperoleh hasil yang maksimal, pembelajaran harus dilakukan secara sistemastis-terstruktur, yakni tercermin dalam strategi pembelajaran tuntas yang dilaksanakan. Strategi mastery learning menurut Hamalik adalah suatu strategi pembelajaran yang diindividualisaikan dengan menggunakan pendekatan kelompok (group-based approach). ${ }^{2}$ Strategi ini memungkinkan para siswa belajar bersama-sama berdasarkan pembatasan bahan pelajaran yang harus dipelajari oleh siswa, sampai tingkat tertentu, penyediaan waktu belajar yang cukup, dan pemberian bantuan kepada siswa yang mengalami kesulitan belajar secara tepat.

Strategi mastery learning dapat diterapkan secara tuntas sebagai upaya untuk meningkatkan mutu pendidikan, terutama dalam level mikro, yaitu mengembangkan individu dalam proses pembelajaran di dalam kelas. Menurut Mulyasa $^{3}$ strategi mastery learning dapat dibedakan dari pembelajaran non-mastery learning terutama dalam hal-hal berikut: 1) Pelaksanaan tes secara teratur untuk memperoleh balikan terhadap bahan yang diajarkan sebagai alat untuk mendiagnosa kemajuan (diagnostic progress test). 2) Siswa baru dapat melangkah pada pelajaran berikutnya setelah ia benar-benar menguasai bahan pelajaran sesuai dengan patokan yang ditetapkan. 3) Pelayanan bimbingan dan penyuluhan terhadap siswa yang gagal mencapai taraf penguasaan penuh, melalui pengajaran korektif yang menurut Marrison merupakan pengajaran kembali, pengajaran tutorial,

\footnotetext{
2 Hamalik, Oemar, Proses Belajar Mengajar, (Bandung : Bumi Akasara, 2003), 84

3 Mulyasa, Standar Kompetensi dan Sertifikasi Guru, (Bandung: PT. Remaja Rosdakarya, 2008), 55
}

FENOMENA, Vol.19 No. 2Oktober 2020 | 225 
restrukturasi kegiatan belajar dan pengajaran kembali kebiasaan-kebiasaan belajar siswa, sesuai dengan waktu yang diperlukan (time needed) masingmasing secara leluasa (time allowed for learning).

Sementara strategi mastery learning yang dikembangkan Bloom (1968) meliputi tiga bagian, yaitu mengidentifikasi prakondisi, mengembangkan prosedur operasional dan hasil belajar. Selanjutnya diimplementasikan dalam pembelajaran klasikal dengan memberikan "bumbu" untuk menyesuaikan dengan kemampuan individual, yang meliputi: 1) Corrective Technique. Semacam pengajaran remedial yang dilakukan dengan pemberian terhadap tujuan yang gagal dicapai oleh siswa, dengan prosedur dan metode sebelumnya. 2) Memberikan tambahan waktu kepada siswa yang membutuhkan atau belum menguasai bahan dan kompetensi secara tuntas. ${ }^{3}$

e) Karakteristik Mastery Learning

Berdasarkan prinsip dan strategi mastery learning sebagaimana yang telah dijelaskan di atas, maka dapat diidentifikasi karakteristik (ciri-ciri) mastery learning, sebagai berikut: (1) pada pokoknya strategi mastery learning adalah jika kepada para siswa diberikan waktu yang cukup, dan mereka di perlakukan secara tepat, maka mereka akan mampu dan dapat belajar sesuai dengan tuntunan kompetensi yang diharapkan, (2) belajar atas tujuan pembelajaran yang hendak dicapai yang ditentukan terlebih dahulu, (3) memperhatikan perbedaan individu (individual difference), (4) menggunakan prinsip siswa belajar aktif (active learning), (5) menggunakan satuan pelajaran terkecil (RPP)_cremental units, (6) menggunakan sistem evaluasi yang kontinyu dan berdasar atas kriteria. ${ }^{3}$ Evaluasi yang digunakan Bisa melalui tes (misalnya tes formatif dan sumatif) atau dalam bentuk non tes (misalnya unjuk kerja [performance] dan portofolio).

f) Faktor-Faktor yang Mempengaruhi Mastery Learning

Para pakar pendidikan berkeyakinan bahwa sebagian besar bahkan semua siswa mampu menguasai bahan pelajaran tertentu sepenuhnya dengan syarat-syarat tertentu serta faktor-faktor yang mempengaruhinya.

3 Lihat Yamin, Martinis, Profesionalisasi Guru h. 125; Mulyasa, Kurikulum Berbasis Kompetensi ......................, h. 55; dan Wena, Made, Strategi Pembelajaran Inovatif Kontemporer h. 184.

3 Warji, R., Program Belajar ${ }^{2}$ Mengajar dengan Prinsip Belajar Tuntas (Mastery Learning), (Surabaya: Institut Dagang, 1983), 32; Suryosubroto, Proses Belajar Mengajar di Sekolah, (Jakarta: PT. Rineka Cipta, 2002), 102-104

226 | FENOMENA, Vol.19 No. 2 Oktober 2020 


\section{Mukhtar}

Berdasarkan teori Carrol, Bloom, Block, dan yang lainnya dapatlah diidentifikasi dan dielaborasikan bahwa mastery learning dipengaruhi oleh faktor-faktor berikut, yaitu: bakat (aptitude), ketekunan belajar (perseverance), kualitas pembelajaran (quality of instruction), kesanggupan untuk menerima pelajaran (ability to learn), dan kesempatan waktu untuk belajar (time allowed for learning). ${ }^{3}$

3

Faktor-faktor tersebut sangat sesuai dengan apa yang disampaikan oleh Al-Jarnuzi dalam kitabnya yang sangat terkenal di kalangan pendidik muslim "Ta'lim al-Muta'allim 'alā Thaariqat at-Ta'allum". Al-Jarnuzi mengadopsi sebuah gubahan sya'ir yang konon berasal dari Ali bin Abi Thalib sebagai berikut. $^{3}$

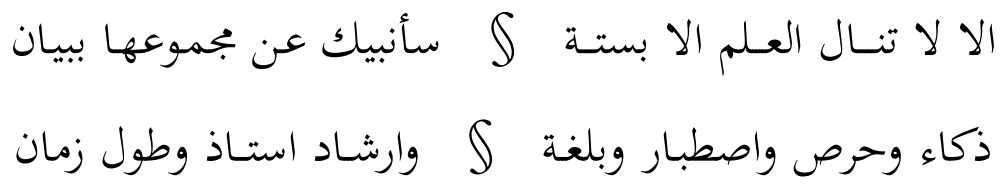

Berdasarkan syi'ir tersebut, dapat dipahami bahwa tidak bisa meraih ilmu (tuntas belajar), tanpa adanya enam faktor, yaitu: (a) Adanya kesanggupan untuk belajar (zaka', intelligence, ability for learning), (b) Rasa ingin tahu (birsun, curiousity) $\rightarrow$ adanya bakat, (c) Kesungguhan/ketekunan belajar (isthibar, perseverance), (d) Bekal biaya (bulgah) $\rightarrow$ adanya sarana pendukung, (e) Petunjuk guru/kualitas pembelajaran (irsyäd ustāz, quality of instruction), dan (f) Waktu yang panjang untuk belajar (thuül al-zamān, time allowed for learning).

Penelitian ini merupakan penelitian lapangan (field research) yang bersifat kualitatif. Pendekatan yang digunakan deskriptif kualitatif dan pengumpulan datanya menggunakan metode observasi, wawancara, dokumentasi dan triangulasi. Analisis data yang digunakan adalah deskriptif analitis dan interpretatif

\section{Temuan Hasil Penelitian dan Pembahasan}

a. Implementasi Mastery Learning Dalam Pembelajaran PAI di SMA Negeri 2 Bogor

1. Indikator Pelaksanaan Mastery Learning dalam Pembelajaran PAI

\footnotetext{
3 Penjelasan lebih lanjut lihat Nasution, Berbagai Pendekatan dalam Proses Belajar Mengajar, (Bandung: Bumi Aksara, 2005), 38-48.

3 Al-Jarnuzi, "Ta'līm al-Muta'ấllim 'alā Thaarīqat at-Ta'allum", (Semarang: Pustaka Alawiyah, t.t.h), 21
}

FENOMENA, Vol.19 No. 2Oktober 2020 | 227 
Pada prinsipnya pelaksanaan strategi mastery learning dalam pembelajaran PAI di SMAN 2 Bogor sama saja dengan strategi lain yang digunakan dalam pembelajaran PAI. Hanya saja ada karakteristik tersendiri yang menjadi ciri khas dan indikator pelaksanaannya, yaitu: 1) Metode pembelajaran yang digunakan variatif dan sangat memperhatikan perbedaan individual, sebagai upaya mencapai standar kompetensi siswa. ${ }^{3}$ 2) Peran guru, bahwa strategi pembelajaran tuntas (mastery learning) menekankan pada peran atau tanggung jawab guru dalam mendorong keberhasilan siswa secara individual. 3) Peran siswa. KTSP berbasis kompetensi sangat menjunjung tinggi dan menempatkan peran siswa sebagai subjek didik. Fokus program pembelajaran bukan pada "Guru dan yang akan dikerjakannya" melainkan pada "Siswa dan yang akan dikerjakannya". Oleh karena itu, pembelajaran tuntas (mastery learning) memungkinkan siswa lebih leluasa dalam menentukan jumlah waktu belajar yang diperlukan. 4) Evaluasi (Penilaian). Sistem evaluasi menggunakan penilaian berkelanjutan, yang ciri-cirinya adalah: (a) ulangan dilaksanakan untuk melihat ketuntasan setiap Kompetensi Dasar (KD), (b) ulangan dapat dilaksanakan terdiri atas satu atau lebih Kompetensi Dasar (KD), (c) hasil ulangan dianalisis dan ditindaklanjuti melalui program remedial, pengayaan, dan program percepatan, (d) ulangan mencakup aspek kognitif dan psikomotor, dan (e) aspek afektif diukur melalui kegiatan inventori afektif seperti pengamatan, kuesioner, skala sikap, dan sebagainya.

2. Pelaksanaan Mastery Learning dalam Pembelajaran PAI di SMAN 2 Bogor

a) Persiapan Pembelajaran

Persiapan pembelajaran pada hakikatnya memproyeksikan tentang apa yang akan dilakukan. Guru yang profesional secara pedagogis adalah yang mampu menyusun perencanaan pembelajaran dengan baik. perencanaan

3 Maksudnya pencapaian Stan'5dar Kompetnsi (SK) dengan indikator hasil belajarnya secara padu dalam pembelajaran PAI, yakni keterpaduan antara ketiga domain dalam diri siswa sebagai performance-nya. Keterpaduan itu menurut Jamaludin mencakup: 1) Kognitif, yakni pembinaan kecerdasan dan ilmu pengetahuan yang luas dan mendalam sebagai penjabaran dari sifat fat?onah Rasulullah. 2) Afektif, yakni pembinaan sikap mental (mental attitude) yang mantap dan matang sebagai penjabaran dari sikap amanah Rasulullah. 3) Psikomotorik, yakni pembinaan tingkah laku (behavior) dan akhlak mulia sebagaimana penjabaran dari sifat $s$ ? ?idiq Rasulullah (Lihat Majid, Abdul, Perencanaan Pembelajaran: Mengembangkan Standar Kompetensi Guru, (Bandung: Remaja Rosdakarya, 2008), 68.

228 | FENOMENA, Vol.19 No. 2 Oktober 2020 


\section{Mukhtar}

dalam mastery learning didasarkan pada pemikiran bahwa sebagian besar siswa dapat belajar dengan baik, dan guru mampu mengajar dengan baik, karenanya perencanaan dan persiapan pembelajaran menjadi suatu keniscayaan (necessary being) bagi setiap guru. Argumentasi ini dibangun dan sesuai dengan sebuah jargon yang terkenal yaitu "plan what you do, and do what you plan, then evaluate what you have planned and have done" (rencanakan apa yang kamu kerjakan, dan kerjakan apa yang kamu rencanakan, kemudian nilai apa yang telah kamu rencanakan dan kerjakan). Karena itu, perencanaan pembelajaran memainkan peranan penting dalam memandu guru melaksanakan tugas sebagai pendidik dalam melayani kebutuhan belajar siswanya. Selain itu, perencanaan pembelajaran juga dimaksudkan sebagai langkah awal sebelum pembelajaran berlangsung.

Persiapan pembelajaran PAI di SMAN 2 Bogor, dengan pendekatan mastery learning berdasarkan pada KTSP berorientasi kompetensi menuntut aktivitas guru PAI untuk mempersiapkan perangkat pembelajaran, yaitu (1) menentukan tujuan dengan mengembangkan silabus, (2) membuat program tahunan dan semester, dan (3) membuat rencana pelaksanaan pembelajaran (RPP), (4) penentuan alat dan prosedur penilaian, dan penentuan standar perilaku dalam bentuk Kriteria Ketuntasan Minimal (KKM).

b) Pelaksanaan Pembelajaran

Kegiatan pembelajaran dengan KTSP berorientasi kompetensi berdasarkan pada konsep belajar tuntas (mastery learning) menghendaki adanya kemungkinan siswa untuk dapat mengembangkan diri secara optimal. Oleh karena itu, penggunaan variasi strategi dan model pembelajaran sangat ditekankan agar perbedaan individu dan kecenderungan yang ada pada siswa dapat diakomodir dan difasilitasi dengan layanan yang baik sesuai dengan karakteristik siswa tersebut. Selain itu, kegiatan pembelajaran dapat dirancang tidak hanya berlangsung di dalam kelas tetapi dapat juga di luar kelas dalam rangka mengaktifkan siswa agar mereka bisa belajar (learning how to learn).

Implementasi prinsip ini dalam pembelajaran PAI dapat dicontohkan dengan pemilihan berbagai masalah aktual yang ada di sekitarnya secara kontekstual untuk dijadikan tema pembelajaran siswa. Siswa diberi kebebasan untuk memilih masalah yang mereka senangi yang ada hubungannya dengan tema pembelajaran, misalnya bahaya narkoba, perkelahian antar pelajar, pernikahan dini, kekerasan dalam pendidikan, dan

FENOMENA, Vol.19 No. 2Oktober 2020 | 229 
sebagainya. Karena dalam konteks PAI, siswa tidak hanya dituntut menguasai materi atau kompetensi dasar tertentu, akan tetapi dituntut pula untuk mengimplementasikan kompetensi tersebut dalam kehidupan seharihari sebagai makhluk individu dan sosial sesuai dengan fungsi dan tugasnya sebagai hamba Allah SWT.

Kegiatan pembelajaran tersebut, dilaksanakan oleh guru PAI sebagai upaya untuk merealisasikan atau mengimplementasikan rancangan pembelajaran yang telah dibuat oleh guru PAI tersebut, baik dalam bentuk silabus, program tahunan atau semester, maupun dalam RPP. Artinya bagaimana guru PAI di SMAN 2 Bogor menerapkan langkah-langkah dan strategi pembelajaran untuk memberikan bantuan dan layanan pada siswa dalam mencapai kompetensi yang hendak dicapai dalam pembelajaran. Selain itu, bagaimana langkah-langkah dan metode, serta strategi yang digunakan dalam kegiatan pembelajaran PAI di sekolah.

Langkah-langkah kongkret pelaksanaan pembelajaran PAI di SMAN 2 Bogor dengan model mastery learning - sebagai manifestasi unit pelajaran (cremental units) yang tertuang dalam RPP—meliputi tiga kegiatan, yaitu: (a) kegiatan awal, (b) kegiatan inti, dan (3) kegiatan penutup.

1) Kegiatan Awal

Kegiatan pertama yang dilakukan guru PAI dalam memulai kegiatan pembelajaran adalah mengkondisikan siswa dalam "kontrak belajar" melalui kegiatan appersepsi, orientasi pembelajaran dan pretest (tes awal).

2) Kegiatan Inti

Kegiatan ini merupakan kegiatan inti dan ruhnya pembelajaran yang dilakukan guru dan siswa secara interrelasi-edukatif. Sebagai perencana pembelajaran sekaligus pelaksana dan penilai kegiatan pembelajaran yang dilakukan, pada kegiatan ini guru tidak lagi memberikan penjelasan singkat, akan tetapi sudah masuk pada proses telling, showing, dan doing. Pada kegiatan inilah variasi pendekatan, strategi, dan metode yang digunakan diupayakan untuk mengantarkan pada ketercapaian kompetensi yang diharapkan. Apalagi jika kompetensinya memasuki wilayah afektif dan psikomotorik, strategi pembelajaran yang menekankan pada doing atau hand menjadi sangat penting, karena penerimaan, tanggapan, dan pemahaman nilai akan secara otomatis berjalan dalam proses pembelajaran. Semakin bervariasi strategi dan metode yang digunakan, maka semakin baik proses dan hasil yang dicapai, karena tidak menjadikan jenuh, melainkan mengantarkan mereka 


\section{Mukhtar}

menikmati proses pembelajaran dengan suasana menyenangkan (joyful learning) dan bermakna (meaningful learning)—belajar PAI akhirnya menjadi mengasyikan.

3) Kegiatan Penutup/Akhir

Pada kegiatan penutup ini (15 menit terakhir) guru dan siswa melakukan tiga kegiatan, yaitu: penarikan kesimpulan, postest dan penugasan. Pertama, membuat kesimpulan (conclusion, summary, natijah) dilakukan untuk memperkuat apa yang telah dipahami dalam proses pembelajaran. Kedua, melakukan postest, yaitu untuk mengukur tingkat penguasaan kompetensi siswa sehingga dapat memberikan informasi untuk program tindak lanjut (remedial, pengayaan, atau percepatan). Hasil postest juga dapat dijadikan feedback (umpan balik) bagi guru untuk melakukan perbaikan proses pembelajaran berikutnya. Postest bisa dalam bentuk tes atau non tes, lisan atau tetulis tergantung pada kompetensi yang dicapai dan prosedur yang telah direncanakan. Penentuan tingkat penguasaannya bisa dilakukan oleh siswa dengan menilai dirinya sendiri berdasarkan kriteria ketuntasan yang telah ditetapkan sebelumnya dengan membandingkan antara hasil pretest dengan postest, atau membandingkan antara kelas yang menggunakan strategi mastery learning dengan yang tidak. Ketiga, memberikan penugasan (jika ada) pada siswa sebagai pekerjaan rumah, baik indvidual maupun kelompok untuk persiapaan pertemuan berikutnya, atau sebagai reinforcement (penguatan) dari apa yang baru saja dipelajarinya.

Secara lebih sederhana, implementasi mastery learning dalam pembelajaran PAI di SMA Negeri 2 Bogor tersebut pada intinya meliputi tahapan-tahapan praktis sebagai berikut: (1) orientasi (orientation), (2) penyajian (presentation), (3) latihan terstruktur (structured practice), (4) latihan terbimbing (guided practice), dan (5) latihan mandiri (independent practice).

c) Evaluasi Pembelajaran

Penilaian (evaluasi) yang dimaksud di sini merupakan padanan kata pengukuran (assesment) yaitu sebagai proses penilaian untuk menggambarkan prestasi yang dicapai oleh seorang siswa sesuai dengan kriteria yang telah ditetapkan. ${ }^{3}$ Pelaksanaan kegiatan penilaian dalam implementasi mastery learning sebagai karakteristik KTSP berbasis kompetensi, berpegang pada lima prinsip penilaian sebagai berikut: (a) sistem belajar tuntas (mastery

3 Syah, Muhibbin, Psikolog 9 Pendidikan Suatu Pendekatan Baru, (Bandung: Rosdakarya, 1999), 141

FENOMENA, Vol.19 No. 2Oktober 2020 | 231 
learning), (b) menggunakan acuan kriteria (criterion-referenced test), (c) penilaian berkelanjutan, (d) mengukur tiga ranah/aspek untuk setiap individu siswa secara adil, dan (e) jujur dan objektif. ${ }^{3}$ Kelima prinsip penilaian Zersebut menjadi acuan pokok guru PAI dalam melaksanakan penilaian. kelimanya penulis jelaskan sebagai berikut:

Berdasarkan pada prinsip penilaian tersebut, guru PAI di SMAN 2 Bogor, senantiasa mengorientasikan penilaian PAI pada indikator pencapaian kompetensi dasar (KD) dalam setiap program pembelajaran yang telah disusun. Secara implelementatif, guru PAI SMAN 2 Bogor dalam melaksanakan penilaian ini, diawali dengan mempersiapkan dan menentukan prosedur dan jenis penilaian, instrumen penilaian untuk ketiga ranah/aspek panilaian (kognitif, afektif, dan psikomotorik).

Penilaian kognitif diperoleh dengan melihat kemampuan siswa dalam menguasai materi pelajaran (kompetensi), melalui tes dan non tes (ulangan harian, mid semester, semester, tugas individu dan kelompok), yang dilaksanakan setelah menyelesaikan satu kompetensi dasar atau beberapa kompetensi dasar dalam waktu tertentu dengan mengacu pada Kriteria Ketuntasan Minimal (KKM) yang telah ditentukan. Penilaian afektif dilakukan dengan pengamatan langsung atau tidak langsung, kuesioner, atau melalui interview. Dengan cara ini guru dapat mengetahui bagaimana sikap, minat, dan kedisiplinan siswa dalam mengikuti kegiatan pembelajaran PAI sekaligus bagaimana siswa mengamalkan dalam kehidupan sehari-hari nilainilai perilaku yang telah dipelajari itu. Karena PAI bersifat aplikatif, harus bisa mencontoh yang baik, dan dapat memberi contoh yang terbaik.

Secara praktis, hasil dari penilaian_dalam bentuk hasil belajar tersebut, oleh guru dilaporkan tingkat penguasaan kompetensi siswa berdasarkan KKM yang telah ditetapkan sebelumnya. Untuk penilaian aspek kognitif dan psikomotorik secara kuantitatif dalam bentuk bilangan bulat (rentang 0-100), sementara untuk aspek afektif secara kualitatif (predikat) yaitu sangat baik (A), baik (B), dan cukup (C). Untuk tahun pelajaran 2017/2018, KKM mata pelajaran PAI di SMAN 2 Bogor ditetapkan 70 untuk kelas X, 71 untuk kelas XI, dan 72 untuk kelas XII. KKM tersebut dicantumkan dalam Laporan Hasil Belajar Siswa(LHBS/Rapor) untuk

3 Depdiknas, Rancangan Pehilaian Hasil Belajar, (Jakarta: Direktorat Jenderal Manajemen Pendidikan Dasar dan Menengah, Direktorat Pembinaan Sekolah Menengah Atas, 2008), 1

232 | FENOMENA, Vol.19 No. 2 Oktober 2020 


\section{Mukhtar}

diketahui siswa dan orang tua/wali. Nilai akhir yang dimasukan dalam LHBS adalah Pengetahuan dan Pemahaman Konsep (PPK) sebagai gabungan dari nilai kognitif dan psikomotorik (dengan angka bulat), dan nilai sikap (afektif) dengan nlai predikat (A, B, atau C).

3. Program Tindak Lanjut Pembelajaran PAI di SMAN 2 Bogor

Tingkat keberhasilan proses belajar mengajar dapat dimanfaatkan untuk berbagai upaya diantaranya adalah berhubungan dengan perbaikan proses pembelajaran (remedial teaching, corrective technique)—sebagai kegiatan korektif, apabila terdapat indikasi kegagalan belajar, baik menyangkut seluruh pokok bahasan/kompetensi atau sebagiannya saja; juga program pengayaan (enrichment), dan program percepatan (acceleration)—sebagai kegiatan reinforcement (penguatan). Ketiga program tersebut merupakan program tindak lanjut-sebagai bagian yang tak terpisahkan-dalam implementasi mastery learning pembelajaran PAI. Ketiganya dilakukan oleh sekolah-dalam hal ini guru PAI - karena guru lebih mengetahui dan memahami pencapaian kemajuan belajar masing-masing siswanya dengan cara memberikan pelayanan yang tepat (appropriate treatment), secara rinci ketiga program tindak lanjut tersebut prosedurnya sebagai berikut:

Gambar 1

Prosedur Pelaksanaan Remedial, Pengayaan dan Percepatan dalam Pembelajaran PAI di SMAN 2 Bogor dengan Konsep Mastery Learning

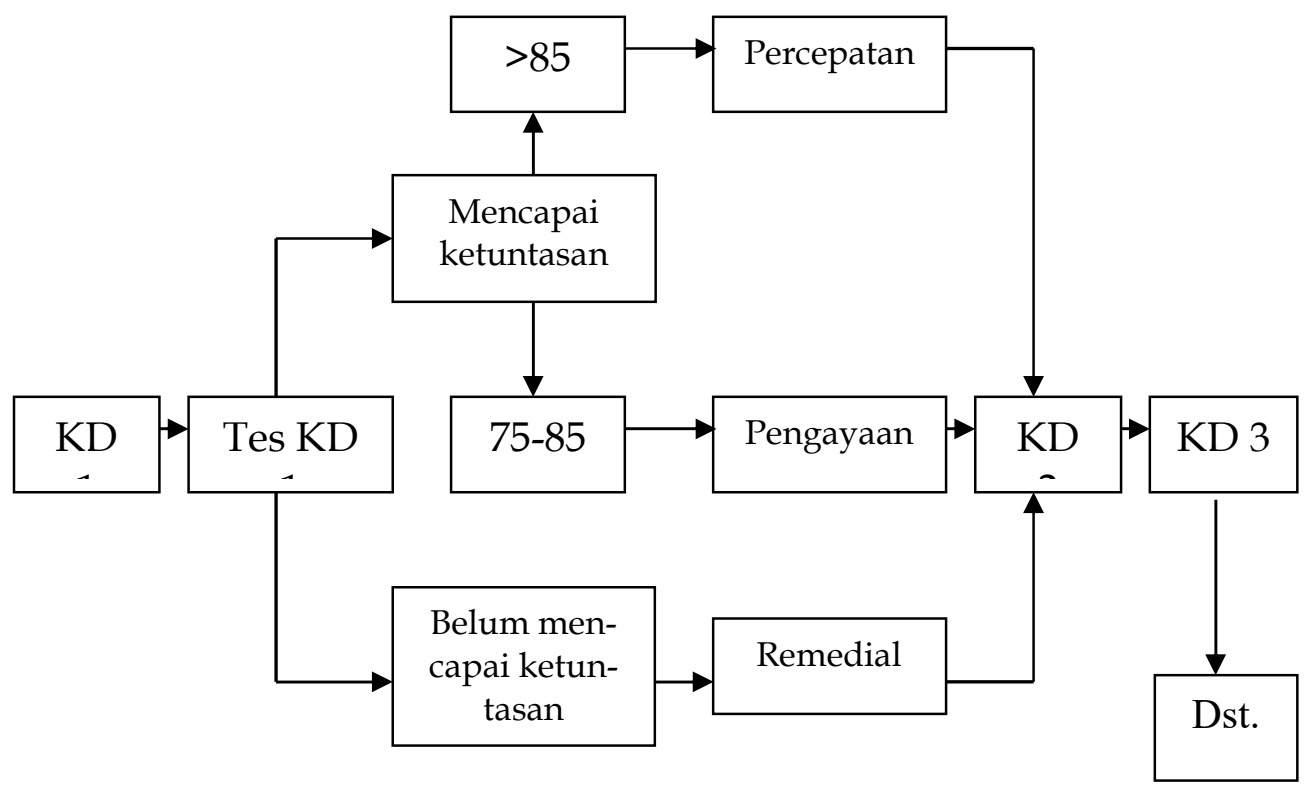

FENOMENA, Vol.19 No. 2Oktober 2020 | 233 
b. Implikasi Mastery Learning Terhadap Pencapaian Standar Kompetensi Siswa Dalam Pembelajaran Pai Di Sma Negeri 2 Bogor

1. Analisis Tujuan dan Standar Kompetensi dalam Pembelajaran PAI di SMA Negeri 2 Bogor

Tujuan merupakan sasaran (purpose) yang harus dicapai oleh siswa dalam proses pembelajaran. Tujuan itu harus bermanfaat bagi siswa. Ia merupakan bentuk perilaku (behavioral objective) dan penampilan (performance objective) yang dapat diukur (measurable) dan observable (dapat diamati). Penetapan tujuan merupakan syarat mutlak (elan vital) bagi guru PAI dalam memilih pendekatan, model atau metode pembelajaran yang tepat dalam menyajikan materi pelajaran. Tujuan ini diuraikan menjadi tujuan khusus dalam istilah kompetensi disebut dengan indikator. Yamin (2003: 128) dalam bukunya Strategi Pembelajaran dalam Kurikulum Berbasis Kompetensi menjelaskan bahwa standar kompetensi (SK) harus dapat dijabarkan menjadi 3-6 kompetensi dasar (KD), kompetensi dasar harus dijabarkan menjadi 2-5 indikator, dan setiap indikator harus dapat melahirkan 3-5 soal ujian (lengkapnya lihat pada lampiran 1 dan 2). Tujuan yang telah dirancang dalam bentuk kompetensi (SK dan KD) dan indikator itu menjadi dasar untuk memilih isi pelajaran (materi pokok) untuk disampaikan pada siswa.

a) Tujuan dan Kompetensi

Tujuan pembelajaran merupakan kemampuan atau keterampilan yang diharapkan dapat dimiliki oleh siswa setelah mereka melakukan proses pembelajaran tertentu. KTSP merupakan kurikulum yang berorientasi pada pencapaian kompetensi. Artinya, tujuan pembelajaran yang harus dicapai oleh siswa dirumuskan dalam bentuk kompetensi/ tujuan pembelajaran yang spesifik dengan istilah indikator keberhasilan belajar. Rumusan indikator hasil belajar dalam KTSP berorientasi kompetensi sangat simpel namun sangat jelas seperti, "Dapat mengidentifikasi bukum tajwid QS. al-Isra': 26-27 dan QS. al-Baqarah: 177" (Siswa tidak disebut secara eksplisist, karena sudah pasti yang harus mencapai kompetensi adalah siswa bukan yang lainnya).

Contoh rumusan tujuan pembelajaran/indikator di atas, tampak hasil belajar yang diharapkan adalah berupa kompetensi yang terukur (measurable) dan observable (dapat diamati) dalam bentuk perilaku (behavior) yang ditampilkan (performance), sehingga setiap guru PAI bisa menilai keberhasilan

pencapaian tujuan sekaligus ketuntasan belajar siswa. Pada posisi ini, 


\section{Mukhtar}

indikator merupakan penanda ketercapaian atau ketidaktercapaian Kompetensi Dasar (KD), begitu juga KD merupakan penanda ketercapaian atau ketidaktercapaian Standar Kompetensi (SK).

b) Hirarki Tujuan dan Kompetensi PAI

Kompetensi merupakan perpaduan dari pengetahuan, keterampilan, nilai, dan sikap yang direfleksikan dalam kebiasaan berpikir dan bertindak. Seseorang yang telah memiliki kompetensi dalam bidang tertentu bukan hanya mengetahui, tetapi juga dapat memahami dan menghayati bidang tersebut yang tercermin dalam pola perilaku (pola pikir, pola sikap, dan pola tindaknya) sehari-hari.

Tujuan pendidikan dan kompetensi memiliki klasifikasi, dari tujuan yang sangat umum sampai tujuan khusus (indikator) yang bersifat spesifik dan dapat diukur (measurable). Secara hirarki tujuan pendidikan menurut kurikulum 1994 adalah Tujuan Pendidikan Nasional (TPN), Tujuan Institusional (TI), Tujuan Kurikuler (TK), dan Tujuan Pembelajaran Umum (TPU). Sedangkan pada KBK/KTSP menurut Permendiknas nomor 22 Tahun 2006 tentang Standar Isi (SI) secara hirarki terdiri dari TPN, Standar Kompetensi Lulusan (SKL), Standar Kompetensi (SK), dan Kompetensi Dasar (KD). Tugas guru dalam merancang pembelajaran agar lebih aplicable (dapat diaplikasikan), measurable, dan observable adalah mengembangkan TPU (dalam Kurikulum 1994) menjadi Tujuan Pembelajaran Khusus (TPK), atau mengembangkan KD (dalam KBK/KTSP 2006) menjadi indikator keberhasilan belajar, lebih jelasnya lihat Tabel berikut:

Tabel 1

Perbandingan Tujuan dan Kompetensi

\begin{tabular}{|l|l|l|}
\hline Kurikulum 1994 & KBK/KTSP 2006 \\
\hline Tujuan Pendidikan Nasional (TPN) & Tujuan Pendidikan Nasional (TPN) \\
\hline Tujuan Institusional (TI) & Standar Kompetensi Lulusan (SKL) \\
\hline Tujuan Kurikuler (TK) & Standar Kompetensi (SK) \\
\hline Tujuan Pembelajaran Umum (TPU) & Kompetensi Dasar (KD) \\
\hline Tujuan Pembelajaran Khusus (TPK) & Indikator \\
\hline
\end{tabular}

FENOMENA, Vol.19 No. 2Oktober 2020 | 235 
Berdasarkan tabel tersebut tampak jelas, secara hirarki Tujuan Pendidikan Nasional (TPN) merupakan tujuan tertinggi dalam Sistem Pendidikan Nasional (SPN) di Indonesia. Tujuan Institusional (TI) sekarang dikenal dengan Standar Kompetensi Lulusan (SKL), Tujuan Kurikuler (TK) sekarang dikenal dengan Standar Kompetensi (SK), Tujuan Pembelajaran Umum (TPU) sekarang dikenal dengan Kompetensi Dasar (KD), sedangkan terakhir yang dikembangkan oleh guru di sekolah sesuai dengan karakteristik dan kondisi sekolah, yakni Tujuan Pembelajaran Khusus (TPK) sekarang dikenal dengan Indikator. Kalau dilihat dari arahnya, arah ke bawah berarti arah penjabaran tujuan/kompetensi, sedangkan arah ke atas berarti arah pencapaian tujuan/kompetensi.

Semakin jelas dan implikatif bahwa indikator merupakan penanda ketercapaian/ketidaktercapaian kompetensi dasar (KD), satu KD dapat dijabarkan menjadi beberapa indikator. Indikator tercapai apabila telah tuntas dikuasai siswa, maka implikasinya KD tercapai; jika KD sudah tercapai dan tuntas, maka dipastikan implikasinya SK tercapai, jika SK sudah tercapai, maka SKL (Standar Kompetensi Lulusan) juga tercapai. Begitu juga sebaliknya, SKL belum tuntas, sebagai implikasi dari SK yang belum tercapai dan belum tuntas, SK belum tercapai dan belum dianggap tuntas karena KD belum tercapai, KD belum tercapai karena indikator-indikatornya belum tercapai. Karena itu, sangatlah jelas bahwa indikator merupakan penanda tercapai atau tidaknya kompetensi dasar, dan berimplikasi pula kepada hirarki kompetensi dan tujuan berikut yang ada di atasnya.

Ketuntasan yang dituntut secara ideal adalah memang 100\%, artinya semua KD dikuasasi secara tuntas dengan sempurna. Di dunia ini tidak ada yang sempurna, yang sempurna hanya Allah SWT. Oleh karena itu, dalam implementasi mastery learning ini, sangat mengakui perbedaan individu dan kecepatan belajar serta ketidaksempurnaan, maka tingkat ketuntasan untuk setiap unit pelajaran (RPP) tidak harus sama dengan tingkat ketuntasaan untuk seluruh rangkaian unit pelajaran, dan kedua-duanya tidak dituntut sempurna atau 100\% berhasil; keberhasilan dan ketuntasan keduanya itu didasarkan pada pencapaian Kriteria Ketuntasan Minimal (KKM) yang telah ditetapkan.

c) Analisis Standar Kompetensi PAI di SMAN 2 Bogor

Standar kompetensi (SK) sebagai tujuan mata pelajaran (sebelumnya disebut tujuan kurikuler) dan Kompetensi Dasar (KD)—sebelumnya disebut 


\section{Mukhtar}

Tujuan Pembelajaran Umum (TPU), penjabarannya secara hirarkis ke bawah. $\mathrm{KD}$ dirumuskan dengan menggunakan kata kerja operasional, yaitu kata kerja yang dapat diamati (observable) dan dapat diukur (measurable). KD merupakan penjabaran lebih lanjut dari SK, SK penjabaran lebih lanjut dari Standar Kompetensi Lulusan (SKL), SKL—sebelumnya disebut tujuan institusional-merupakan penjabaran dari Standar Isi (SI) dan merupakan manifestasi dari Tujuan Pendidikan Nasional (TPN) Indonesia. Kompetensi Dasar (KD) dalam implementasi pembelajaran, harus dijabarkan lagi menjadi indikator-indikator keberhasilan belajar. Secara aplikatif, SK dapat dijabarkan menjadi 3-6 KD, dan KD dapat dijabarkan menjadi 2-5 indikator, dan setiap indikator harus dapat melahirkan 3-5 soal ujian (tes).

Berdasarkan hal tersebut, jelas bahwa indikator merupakan penjabaran kompetensi dasar secara spesifik yang dapat dijadikan ukuran untuk mengetahui ketercapaian hasil pembelajaran. Indikator dirumuskan dengan kata kerja operasional yang bisa dimati (observable) diukur (measurable) dan dibuat instrumen penilaiannya. Indikator pencapaian hasil belajar berfungsi sebagai tanda-tanda penampilan (performance) yang menunjukkan terjadinya perubahan perilaku (behavior change) pada siswa baik kognitif, afektif, maupun psikomotorik. Performance tersebut lebih spesifik dan dapat diamati.

Jika serangkaian indikator hasil belajar telah tampak pada diri siswa, maka target Kompetensi Dasar tersebut telah tercapai. Apabila Kompetensi Dasar (minimal) telah tercapai oleh siswa, maka target Standar Kompetensi telah tercapai, begitu seterusnya. Begitu juga sebaliknya, apabila indikator keberhasilan belum dikuasai (belum tuntas), maka target Kompetensi Dasar yang dipelajari belum tercapai, secara otomatis akan berimplikasi pada ketercapaian Standar Kompetensi. Karenanya apabila siswa belum menguasai kompetensi dasar tertentu, maka yang besangkutan belum bisa melanjutkan pada kompetensi dasar berikutnya, tetapi harus mengikuti program perbaikan (remedial) sebagai "korektif" sehingga mencapai ketuntasan minimal sebagaimana yang telah ditetapkan sebelumnya.

Standar Kompetensi (SK) mata pelajaran PAI di SMAN 2 Bogor berisi batas kemampuan minimal yang harus dicapai setelah siswa menyelesaikan proses pembelajaran PAI di SMAN 2 Bogor yang diikutinya. SK inisebagaimana telah dijelaskan sebelumnya-kemudian dijabarkan lebih rinci lagi menjadi kompetensi dasar. Mengingat ruang lingkup mata pelajaran PAI ada 5 (lima) aspek, yaitu: al-Qur'an, Keimanan, Akhlak, Fiqh/Ibadah, dan 
Tarikh, maka analisis SK mata pelajaran PAI di SMAN 2 Bogor juga mencakup kelima aspek tersebut.

Standar Kompetensi (SK) tersebut apabila dianalisis berdasarkan ruang lingkup PAI (aspeknya), maka akan terlihat bahwa totalitas SK yang harus dicapai siswa dalam pembelajaran PAI di SMAN 2 Bogor adalah terdiri dari 37 SK. Berdasarkan pengamatan dan studi dokumenter terhadap silabus yang disusun oleh guru PAI dan wawancara langsung, maka dapat diidentifikasi dan dideskripsikan bahwa 37 SK tersebut dijabarkan menjadi $103 \mathrm{KD}$ dan 279 indikator yang harus dicapai oleh siswa selama mengikuti pendidikan di SMAN 2 Bogor. Adapun rincian dan distribusinya sebagai berikut: (1) Kelas X, terdiri dari 12 SK, 34 KD, dan 106 indikator; (2) Kelas XI terdiri dari 13 SK, 36 KD, dan 86 indikator; dan (3) Kelas XII terdiri dari $12 \mathrm{SK}, 33 \mathrm{KD}$, dan 87 indikator. Sementara distribusi dan pemetaan berdasarkan aspeknya adalah sebagai berikut: (1) Aspek al-Qur'an terdiri dari 9 SK, 27 KD, dan 73 indikator; (2) Aspek keimanan terdiri dari 6 SK, 15 KD, dan 37 indikator; (3) Aspek akhlak terdiri dari 9 SK, 27 KD, dan 78 indikator; (4) Aspek fiqh terdiri dari 7 SK, 20 KD, dan 59 indikator; dan (5) Aspek tarikh terdiri dari $6 \mathrm{SK}, 14 \mathrm{KD}$, dan 32 indikator.

Berdasarkan uraian tersebut tampak bahwa standar kompetensi dapat dicapai apabila siswa telah menyelesaikan kompetensi dasar secara tuntas (mastery), kemudian kompetensi dasar akan bisa dicapai apabila telah menyelesaikan indikator secara tuntas. Tampak pula tahapan pembelajaran yang ditempuh secara sistematis dan terarah untuk menyelesaikan dan menguasai kompetensi yang harus dikuasai secara individual, apabila tahapan pertama belum tuntas, maka ia tidak boleh melanjutkan pada tahapan kompetensi berikutnya. Implikasinya, apabila standar kompetensi di kelas X atau XI belum tuntas, maka ia tidak boleh naik ke kelas berikutnya yang lebih tinggi, tetapi harus mengikuti program perbaikan (remedial) ataumeminjam istilah Bloom disebut "corrective technique"-untuk mencapai ketuntasan minimal yang telah ditentukan berdasarkan Kriteria Ketuntasan Minimal (KKM) pada kelas yang bersangkutan. Bahkan dalam skala kecil misalnya dalam satu unit pelajaran (RPP) siswa belum mencapai ketuntasan pada KD tertentu, maka ia tidak boleh mengikuti KD pada unit pelajaran berikutnya sebelum ia mencapai ketuntasan minimal pada KD yang bersangkutan dengan mengikuti program perbaikan (remedial teaching, corrective technique).

238 | FENOMENA, Vol.19 No. 2 Oktober 2020 
2. Pengembangan KKM dalam Pembelajaran PAI di SMAN 2 Bogor

Salah satu prinsip penilaian pada kurikulum berbasis kompetensi adalah menggunakan acuan kriteria (criterion referenced). Kriteria Ketuntasan Minimal (KKM) adalah kriteria paling minimal untuk menyatakan siswa mencapai ketuntasan. ${ }^{3}$ Kriteria ketuntasan menunjukkan prosentase pencapaian ketuntasan sehingga dinyatakan dengan angka maksimal 100 (seratus) sebagai kriteria ketuntasan ideal. Nilai KKM dinyatakan dalam bentuk bilangan bulat rentang 0-100. Target ketuntasan secara nasional diharapkan mencapai minimal 75. Dalam hal ini, satuan pendidikan (SMAN 2 Bogor) dapat memulai dari KKM minimal di bawah target nasional kemudian ditingkatkan secara bertahap setiap tahunnya. Satuan pendidikan harus berupaya semaksimal mungkin untuk melampaui KKM yang telah ditetapkan. Keberhasilan pencapaian KKM merupakan salah satu tolok ukur kinerja satuan pendidikan dalam menyelenggarakan pendidikan.

Penetapan KKM ini dilakukan dalam forum Musyawarah Guru Mata Pelajaran (MGMP) setelah dilakukan analisis ketuntasan belajar minimal dengan memperhatikan kompleksitas, daya dukung, dan intake siswa untuk mencapai ketuntasan kompetensi Dasar (KD) dan Standar Kompetensi (SK). Nilai KKM setiap KD merupakan rata-rata nilai setiap indikator yang terdapat dalam KD tersebut. Implikasinya, siswa dinyatakan telah mencapai ketuntasan belajar untuk KD tertentu apabila yang bersangkutan telah mencapai ketuntasan belajar minimal yang telah ditetapkan untuk seluruh indikator pada KD tersebut.

Kriteria Ketuntasan Minimal (KKM) setiap Standar Kompetensi (SK) merupakan rata-rata KKM dari KD yang terdapat dalam SK tersebut. Sedangkan KKM mata pelajaran (PAI) merupakan rata-rata dari semua KKM-SK yang terdapat dalam satu semester atau satu tahun pembelajaran, dan dicantumkan dalam Laporan Hasil Belajar Siswa (LHBS/Rapor) sebagai laporan kepada orang tua/wali siswa.

Jadi, KKM yang harus dikembangkan oleh guru PAI atau forum guru mata pelajaran PAI di sekolah ada empat yaitu: KKM indikator, KKM-KD, KKM-SK, dan KKM mata pelajaran PAI. Adapun penetapan KKM ini

3 Depdiknas, Penetapan Kritefia Ketuntasan Minimal (KKM), (Jakarta: Departemen Pendidikan Nasional, Dirjen Manajemen Pendidikan Dasar dan Menengah, Direktorat Pembinaan Sekolah Menengah Atas, 2008), 3

FENOMENA, Vol.19 No. 2Oktober 2020 | 239 
dilakukan dengan memperhatikan hal-hal sebagai berikut: (1) Tingkat kompleksitas, yaitu kesulitan dan kerumitan setiap indikator, kompetensi dasar, dan standar kompetensi yang harus dicapai siswa. (2) Daya dukung, yaitu kemampuan sumber daya pendukung dalam penyelenggaraan pembelajaran di sekolah yang bersangkutan. (3) Intake siswa, yaitu tingkat kemampuan rata-rata (intake) siswa di sekolah yang bersangkutan. ${ }^{3}$ Intake merupakan tingkat kemampuan rata-rata siswa yang meliputi hasil seleksi penerimaan siswa baru (PSB), Nilai Ujian Nasional/Sekolah, dan rapor SMP/MTs. Sedangkan untuk kelas XI dan XII berdasarkan pada kemampuan siswa di kelas sebelumnya.

Untuk memudahkan analisis setiap indikator, perlu membuat skala penskoran yang telah disepakati dalam MGMP sekolah, yaitu: ${ }^{4}$

Tabel 2

\section{Cara Menentukan KKM Indikator}

\begin{tabular}{|l|l|l|l|}
\hline Aspek yang Dianalisis & \multicolumn{4}{|l|}{ Kriteria Penskoran } \\
\hline \multirow{2}{*}{ Kompleksitas } & Tinggi & Sedang & Rendah \\
& 1 & 2 & 3 \\
\hline \multirow{2}{*}{ Daya Dukung } & Tinggi & Sedang & Rendah \\
& 3 & 2 & 1 \\
\hline \multirow{2}{*}{ Intake Siswa } & Tinggi & Sedang & Rendah \\
& 3 & 2 & 1 \\
\hline
\end{tabular}

Sebagai contoh, jika indikator setelah dianalisis memiliki kompleksitas tinggi, daya dukung tinggi, dan intake siswa sedang, maka nilai KKM-nya adalah:

$$
\frac{1+3+2}{9} \times \quad 100=66,7
$$

Nilai KKM adalah angka bulat, maka nilai KKM-nya adalab 67. Sedangkan angka 9 merupakan skor maksimal dari ketiga aspek KKM tersebut.

\footnotetext{
3 Diadaptasi dari Ibid, h. 6-8. 9

4 Ibid, h. 8.
}

240 | FENOMENA, Vol.19 No. 2 Oktober 2020 


\section{Mukhtar}

Setelah penentuan KKM indikator, maka langkah selanjutnya adalah bagaimana menentukan KKM mata pelajaran, KKM-SK, KKM-KD, dan indikator secara tabulasi. Berikut penulis sajikan penentuan KKM per KD dan Indikator, lalu bisa ditentukan KKM-SK dan KKM mata pelajaran PAI.

KKM masing-masing indikator dapat ditentukan dengan memperhatikan kompleksitas, daya dukung, dan intake siswa dengan skornya masing-masing. Rata-rata KKM indikator yang ada, maka menjadi KKM Kompetensi Dasar (KD). Setelah KKM-KD diketahui maka KKM Standar Kompetensi (SK) juga mudah diketahui, yaitu rata-rata dari KKM-KD yang ada pada SK tersebut, dan begitu seterusnya. Terakhir, setelah KKM-SK diketahui seluruhnya untuk satu semester atau satu tahun, maka dapat ditentukan KKM mata pelajaran PAI, yang akan dimasukkan dalam Laporan Hasil Belajar (LBH/Rapor) siswa dan dilaporkan pada orang tua. Keempat KKM tersebut harus disosialisaikan pada siswa dan orang tua serta disyahkan oleh pihak sekolah.

3. Implikasi Mastery Learning Terhadap Pencapaian Standar Kompetensi

Pada dasarnya hidup manusia ini hanyalah sekedar mengadakan pilihan (life is just a matter of choice), dalam terminologi al-Qur'an disebut dengan konsep "ikhtiar" (lihat Q.S. al-Ra'd [13]: 11). Di sinilah para guru berperan untuk memberikan preference (menentukan pilihan) yang terbaik bagi para siswanya dalam mentransformasikan dan menginternalisasikan nilai-nilai pendidikan yang benar. Strategi pembelajaran mana yang secara edukatif dapat membangun karakter (educating for characters building) siswa untuk menguasai kompetensi secara tuntas dengan cara-cara yang konstruktifedukatif, bermakna (meaningful learning), dan menyenangkan (joyful learning), serta menciptakan suasana belajar bagaimana agar bisa belajar (learning how to learn). Menghindarkan sejauh mungkin kesalahan mendidik (demagog), ataumeminjam istilah Halim (1985: 80)—disebut "wan-edukasi" (dis education). Menghindarkan pembelajaran yang dapat merusak karakter secara destruktif (merusak) dalam mencapai ketuntasan belajar dan penguasaan kompetensi yang diharapkan. Artinya, pembelajaran diarahkan pada pemberdayaan (empowering) segala potensi siswa dengan segala karakteristik dan perbedaannya. Di sini jelas sebagaimana Muhadjir (1993: 17) menjelaskan bahwa program pendidikan harus mampu menumbuhkembangkan daya kreativitas siswa, melestarikan nilai-nilai Ilahi, serta membekali siswa dengan

FENOMENA, Vol.19 No. 2Oktober 2020 | 241 
kemampuan (kompetensi) yang produktif. Hal ini berarti pembelajaran PAI ketuntasannya dapat berorientasi mondial (duniawi) dan transendensi-immanensi (ukkrawi), artinya sebagai usaha perbaikan kualitas manusia yang berkesinambungan (continuous quality improvement) agar memiliki nilai jual (marketable) di masyarakat, bahagia dunia dan bahagia di akhirat. ${ }^{4}$

Argumentasi tersebut menjadi penting terhadap implementasi mastery learning dalam pembelajaran PAI, implikasinya terhadap pencapaian Standar Kompetensi (SK) yang telah ditetapkan. Implikasinya adalah sebagai berikut:

a. Dalam kondisi yang optimal (faktor pendukung lengkap), sebagian besar siswa menguasai KD dan SK secara tuntas.

b. Guru bertugas mencari setiap kemungkinan untuk menciptakan kondisi pembelajaran yang optimal termasuk waktu, metode, media serta umpan balik (feedback) bagi siswa.

c. Siswa adalah individu-individu yang berbeda, oleh karena itu kondisi optimal masing-masing individu berbeda, secara otomatis bentuk pelayanan yang diberikan juga berbeda. Karena individu siswa memiliki gaya dan kecepatan belajar yang berbeda, hasilnya pun bisa berbeda.

d. Siswa seharusnya mengerti hakikat tujuan serta prosedur pembelajaran. Oleh karena itu, perumusan tujuan pembelajaran dalam bentuk indikator sebagai penjabaran KD, harus disosialisikan pada siswa agar siswa kompetensi apa yang harus dikuasai dan pembelajaran yang bagaimana yang akan dilaksanakan.

e. Sangat bermanfaat bila pelajaran diperinci dalam satuan-satuan pelajaran yang terkecil, dengan cara membuat RPP dan selalu diadakan post test setelah akhir satuan pelajaran sebagai umpan balik (feedback).

f. Kegiatan pembelajaran akan lebih efektif bila siswa membentuk kelompok-kelompok belajar yang kecil dan dapat bertemu secara teratur untuk saling membantu mengatasi kesulitan dengan peer tutorial (tutor sebaya).

g. Penilaian akhir harus didasarkan pada tingkatan penguasaan Kompetensi Dasar (KD) dan Standar Kompetensi (SK) mata pelajaran PAI itu sendiri.

h. Program tindak lanjut (remedial, pengayaan, dan percepatan) menjadi keniscayaan (necessary being) yang tak terpisahkan dalam mengimplementasikan mastery learning dalam pembelajaran PAI. 


\section{Mukhtar}

i. Implikasi pedagogis yang diharapkan melalui mastery learning adalah penguasaan Standar Kompetensi secara terpadu (kognitif, afektif, dan psikomotorik) dalam pembelajaran PAI di SMAN 2 Bogor, sehingga pada akhirnya akan berimplikasi pula pada pencapaian tujuan Pendidikan Nasional dan tujuan Pendidikan Islam itu sendiri, baik secara mikro maupun secara makro, tentunya apabila pembelajaran (PAI) dilaksanakan dengan baik dan benar serta sistematis, salah satunya dengan strategi mastery learning ini.

\section{SIMPULAN}

Berdasarkan pada deskripsi hasil informasi dan temuan yang telah penulis sajikan pada bagian sebelumnya, baik berasal dari data-data literatur yang terkait dengan penelitian ini, maupun data-data yang diperoleh dari hasil penelitian di lapangan dapat penulis simpulkan sebagai berikut:

Hasil penelitian menunjukkan bahwa SMA Negeri 2 Bogor telah mengimplementasikan strategi/model mastery learning dalam pembelajarantermasuk PAI, terutama sejak diberlakukannya Kurikulum Berbasis Kompetensi (KBK) tahun 2004, dan Kurikulum Tingkat Satuan Pendidikan (KTSP) tahun 2006. Implementasi mastery learning dalam pembelajaran PAI di SMA Negeri 2 Bogor, ditunjukkan melalui indikator pelaksanaannya, yaitu: (a) metode pembelajaran yang digunakan sangat variatif dan memperhatikan keunikan individual siswa. Pendekatan yang digunakan lebih menekankan pada interaksi antara siswa dengan materi belajar secara aktif (active learning), (b) guru PAI bukan satu-satunya sumber belajar, tetapi sebagai fasilitator, dan pembimbing belajar siswa, (c) menempatkan siswa sebagai subjek didik (student centered), dan (d) evaluasi belajarnya menggunakan asumsi bahwa semua siswa pada hakekatnya dapat belajar apa saja, hanya saja waktu yang diperlukan berbeda pada setiap siswa.

Hasil penelitian juga menunjukkan bahwa implementasi mastery learning di SMA Negeri 2 Bogor, ditandai dengan langkah-langkah pembelajaran yang praktis dan sistematis, yakni membuat perencanaan yang baik dengan berdasar pada jargon "plan what you do, and do what you plan, then evaluate what you have planned and have done" (rencanakan apa yang kamu kerjakan, dan kerjakan apa yang kamu rencanakan, kemudian nilai apa yang telah kamu rencanakan dan kerjakan). Langkah tersebut meliputi: Pertama, persiapan pembelajaran, yakni membuat perangkat pembelajaran. Kedua, pelaksanaan 
pembelajaran dalam unit terkecil pelajaran (RPP, cremental units), meliputi: kegiatan awal, kegiatan inti, dan kegiatan penutup. Ketiga, pelaksanaan penilaian untuk mengetahui tingkat penguasaan siswa, menggunakan penilaian berbasis kelas (classroom assessment) dan berkelanjutan. Hal ini ditandai dengan dilaksanakannya program tindak lanjut berupa program perbaikan (remedial teaching), program pengayaan (enrichment), dan program percepatan (acceleration), sebagai wujud untuk memberikan layanan yang tepat (appropriate treatment) pada siswa dalam pembelajaran.

Hasil penelitian menunjukkan bahwa SK pada mata pelajaran PAI di SMA Negeri 2 Bogor, pencapaiannya merupakan suatu keniscayaan (necessary being) yang tak bisa ditawar-tawar lagi, karena berisi batas kemampuan minimal yang harus dicapai setelah siswa menyelesaikan proses pembelajaran PAI di SMA Negeri 2 Bogor yang diikutinya. SK tersebut dijabarkan dalam Kompetensi Dasar (KD) dan KD oleh guru dijabarkan secara lebih operasional menjadi indikator keberhasilan belajar. Pencapaian indikator hasil belajar ini, akan berimplikasi pada tingkat kemampuan dan performance siswa orang perorang yang dapat diukur (measurable) dan diamati (observable), bukan kemampuan perkelas sebagai indikator keberhasilan belajarnya. Sehingga implikasi selanjutnya, siswa boleh melanjutkan ke kompetensi berikutnya setelah dinyatakan tuntas pada kompetensi sebelumnya.

Secara praktis menunjukkan bahwa implikasi mastery learning pada upaya pencapaian SK siswa dalam pembelajaran PAI di SMA Negeri 2 Bogor, didasarkan pada KKM yang ditetapkan guru/forum guru dengan mempertimbangkan kompleksitas materi, intake (kemampuan rata-rata) siswa, dan daya dukung sekolah. Ketercapaian atau ketidaktercapaian SK itu akan sangat tergantung pada ketercapaian atau ketidaktercapaian KD, dan ketercapaian atau ketidaktercapaian KD juga sangat tergantung pada ketercapaian atau ketidaktercapaian indikator keberhasilan belajar. Bahkan lebih jauh lagi, apabila SK telah tercapai-berdasarkan KKM-akan berimplikasi pula pada pencapaian Standar Kompetnsi Lulusan (SKL), dan apabila SKL tercapai, maka Tujuan Pendidikan Nasional (TPN) juga bisa tercapai, sehingga pada akhirnya tujuan pendidikan Islam $^{4}$ secara khusus diharapkan bisa tercapai pula, begitu pula sebaliknya.

4 Setiap sistem pendidikan, dipastikan memiliki arah dan tujuan akhir yang ingin dicapai oleh sistem itu. Begitu juga halnya sistem pendidikan Islam, tentunya tujuan didasarkan pada sumbernya (al-Qur'an dan al-Hadits) dan pemikiran para pakar

244 | FENOMENA, Vol.19 No.2Oktober 2020 
Mukhtar

\section{DAFTAR PUSTAKA}

al-Abrasyi, Mohammad 'Athiyah. Dasar-Dasar Pokok Pendidikan Islam, terj. Bustami A. Ghani dan Johar Bahry, (Jakarta: Bulan Bintang, 1993)

Azizy, A. Qodry. Pendidikan [Agama] Untuk Membangun Etika Sosial. (Semarang: Aneka Ilmu, 2002)

Karim, M. Rusli. "Pendidikan Islam Sebagai Upaya Pembebasan Manusia", dalam Muslih Usa (Editor), Pendidikan Islam di Indonesia Antara Cita dan Fakta, Yogyakarta: Tiara Wacana, 1991.

Mulyasa. Kurikulum Berbasis Kompetensi: Konsep, Karakter, dan Implementasi, (Bandung: PT. Remamaja Rosdakarya, 2006.

Darsono, Max, dkk., Belajar dan Pembelajaran, (Semarang: IKIP Press, 2001)

Depdiknas. Pedoman Khusus Pengembangan Silabus dan Penilaian, Jakarta: Dirjen

Dikdasmen: Direktorat Dikmenum, 2003)

Depdiknas, Rancangan Penilaian Hasil Belajar, Jakarta: Direktorat Jenderal

Manajemen Pendidikan Dasar dan Menengah, Direktorat Pembinaan

Sekolah Menengah Atas, 2008)

Depdiknas. The Mastery Learning for the 2004 Curriculum. Jakarta: Dirjen

Dikdasmen Direktorat Pendidikan Menengah Umum, 2003.

Depdiknas. Model Penilaian Kelas Kurikulum Berbasis Kompetensi, Dirjen

Dikdasmen: Direktorat Dikmenum, 2007)

pendidikan muslim dengan rumusan yang singkat dan sederhana agar lebih aplikatif idealisasinya. Pada konsep inilah menurut Zuhairini tujuan adalah dunia cita, yakni suasana ideal yang ingin diwujudkan. Suasana ideal itu tercermin pada formulasi (rumusan) tujuan akhir (ultimate aims of education) yang diformulasikan secara singkat dan padat (Zuhairini, Filsafat Pendidikan Islam, Jakarta: Bumi Aksara, 1992, h. 159). Tujuan akhir pendidikan Islam adalah terwujudnya manusia sebagai 'abid dan hamba Allah yang baik (lihat an-Nahlawy, Abdurrahman, 1992, Prinsip-Prinsip dan Metode Pendidikan Islam, terj. Herry Noer Ali, Bandung: CV. Diponegoro, 1992, h. 162; Jalal, Abdul Fattah, 1988, Asas-Asas Pendidikan Islam, terj. Herry Noer Ali, Bandung: CV. Diponegoro, 1988, h. 119), terbentuknya manusia yang berakhlak mulia (al-Djamali, Fadhil, 1993, Menerebas Krisis Pendidikan Islam, terj. M. Arifin, Jakarta: Golden Trayon Press, 1993, h. 87; al-Abrasyi, Mohammad 'Athiyah, 1993: Dasar-Dasar Pokok Pendidikan Islam, terj. Bustami A. Ghani dan Johar Bahry, Jakarta: Bulan Bintang, 1993, h. 103), terbentuknya kepribadian muslim (Marimba, Ahmad D., 1986, Pengantar Filsafat Pendidikan Islam, Bandung: PT. Alma'arif, 1986, h. 19), terbentuknya manusia yang baik (Qutb, Mohammad, 1984, Sistem Pendidikan Islam, Jakarta: Bumi Aksara, 1984, h. 39) dan bertaqwa (Tafsir, Ilmu Pendidikan dalam Perspektif Islam, Bandung: Remaja Rosdakarya, 1992, h. 48).

FENOMENA, Vol.19 No. 2Oktober 2020 | 245 
Depdiknas, Pedoman Pembelajaran Tuntas (Mastery Learning), (Jakarta: Dirjen Dikdasmen: Direktorat Pendidikan Menengah Umum, 2004)

al-Djamali, Fadhil. Menerebas Krisis Pendidikan Islam, terj. M. Arifin, (Jakarta: Golden Trayon Press, 1993)

Ghofar, Irfan Abdul dan Muhammad Jamil. Reformulasi Rancangan Pembelajaran Agama Islam: Pedoman Dosen dan Mahasiswa. (Jakarta: Nur Insani, 2003)

Hamalik, Oemar, Proses Belajar Mengajar, (Bandung : Bumi Akasara, 2003)

Jalal, Abdul Fattah, Asas-Asas Pendidikan Islam, terj. Herry Noer Ali, (Bandung: CV. Diponegoro, 1988)

Al-Jarnuzi, "Ta'lim al-Muta'allim 'alā Thaarīat at-Ta'allum", (Semarang: Pustaka Alawiyah, t.t.h)

John dan Hassan Shadily, Kamus Inggris Indonesia, (Jakarta: Gramedia, 1996)

Kunandar. Guru Profesional: Implementasi Kurikulum Tingkat Satuan Pendidikan (KTSP) dan Sukses dalam Sertifikasi Guru. (Jakarta: PT. RajaGrafindo Persada, 2007)

Majid, Abdul. Perencanaan Pembelajaran: Mengembangkan Standar Kompetensi Guru. (Bandung: Remaja Rosdakarya, 2008)

Marimba, Ahmad D., Pengantar Filsafat Pendidikan Islam, (Bandung: PT. Alma'arif, 1986)

Martinis, Profesionalisasi Guru dan Implementasi KTSP, (Jakarta: Gaung Persada Press, 2007)

Muhaimin, et.al., Paradigma Pendidikan Islam: Upaya Mengefektifkan Pendidikan Agama Islam di Sekolah, (Bandung: Remaja Rosdakarya, 2002)

Mulyasa, Standar Kompetensi dan Sertifikasi Guru, (Bandung: PT. Remaja Rosdakarya, 2008)

Mulyasa. Kurikulum Berbasis Kompetensi: Konsep, Karakter, dan Implementasi, (Bandung: PT. Remamaja Rosdakarya, 2006)

Naim, Naginun dan Achmad Patoni. Materi Penyusunan Desain Pembelajaran Pendidikan Agama Islam. (Yogyakarta, Pustaka Pelajar, 2007)

Nasution, Berbagai Pendekatan dalam Proses Belajar Mengajar, (Bandung: Bumi Aksara, 2005)

an-Nahlawy, Abdurrahman. Prinsip-Prinsip dan Metode Pendidikan Islam, terj. Herry Noer Ali, Bandung: CV. Diponegoro, 1992,

246 | FENOMENA, Vol.19 No. 2 Oktober 2020 


\section{Mukhtar}

Nurhadi dan Agus Gerrad Senduk. Pembelajaran Contextual (Contextual Teaching and Learning) dan Penerapannya dalam KBK. (Malang: Universitas Negeri Malang, 2003)

Poerwadarminta, W.J.S., Kamus Umum Bahasa Indonesia, (Jakarta: Balai Pustaka, 1997)

Qutb, Mohammad. Sistem Pendidikan Islam, (Jakarta: Bumi Aksara, 1984)

Sanjaya, Wina. Strategi Pembelajaran: Berorientasi Standar Proses Pendidikan. (Jakarta: Kencana Prenada Media Group, 2008)

Sutrisno. Revolusi Pendidikan di Indonesia, Membahas tentang Metode dan Teknik Berbasis Kompetensi, (Yogyakarta: Ar-ruz, 2005)

Suryosubroto, Proses Belajar Mengajar di Sekolah, Jakarta: PT. Rineka Cipta, 2002)

Syah, Muhibbin. Psikologi Pendidikan Suatu Pendekatan Baru. (Bandung: Rosdakarya, 1999)

Tafsir. Ilmu Pendidikan dalam Perspektif Islam, (Bandung: Remaja Rosdakarya, 1992)

Tim Peneliti Depag RI. Pedoman Penilaian Pendidikan Agama Islam Berbasis Kompetensi di Sekolah Menengah Atas, Jakarta: Departemen Agama RI.

Yamin, Martinis. Sertifikasi Profesi Keguruan di Indoenesia. (Jakarta: Gaung Persada Press, 2006)

Warji, R., Program Belajar Mengajar dengan Prinsip Belajar Tuntas Mastery Learning), (Surabaya: Institut Dagang, 1983

Zuhairini, Filsafat Pendidikan Islam, (Jakarta: Bumi Aksara, 1992) 